\title{
Paracoccus koreensis sp. nov., isolated from anaerobic granules in an upflow anaerobic sludge blanket (UASB) reactor
}

\author{
Hyun-Jun La, ${ }^{1}$ Wan-Taek Im, ${ }^{1}$ Leonid N. Ten, ${ }^{1,2}$ Myung Suk Kang, ${ }^{1}$ \\ Do-Yun Shin ${ }^{1} \dagger$ and Sung-Taik Lee ${ }^{1}$
}

Correspondence

Sung-Taik Lee

e_stlee@kaist.ac.kr

\author{
${ }^{1}$ Department of Biological Sciences, Korea Advanced Institute of Science and Technology, \\ 373-1, Guseong-dong, Yuseong-gu, Daejeon 305-701, Republic of Korea \\ ${ }^{2}$ National University of Uzbekistan, VUZ-gorodok, Tashkent 700-174, Uzbekistan
}

\begin{abstract}
A Gram-negative, short rod- to coccus-shaped, non-spore-forming bacterium $\left(\mathrm{ChO}^{\top}\right)$ was isolated from granules in an upflow anaerobic sludge blanket (UASB) reactor. On the basis of 16S rRNA gene sequence similarity, strain $\mathrm{Ch05}^{\top}$ was shown to belong to the subclass $\alpha$-Proteobacteria, being related to Paracoccus solventivorans (97.5\%), Paracoccus alkenifer (96.9\%) and Paracoccus kocurii (96.4\%). The phylogenetic distance from Paracoccus species with validly published names was always less than $96 \%$. Physiological and chemotaxonomic data (major ubiquinone, $\mathrm{Q}-10$; major fatty acids, $\mathrm{C}_{18: 1}$ and $\mathrm{C}_{18: 0}$ ) supported the affiliation of strain $\mathrm{ChO}^{\top}$ to the genus Paracoccus. The results of DNA-DNA hybridization and physiological and biochemical tests allowed genotypic and phenotypic differentiation of strain $\mathrm{ChO5}^{\top}$ from the 17 Paracoccus species with validly published names. $\mathrm{Ch} 05^{\top}$ therefore represents a novel species, for which the name Paracoccus koreensis sp. nov. is proposed. The type strain is $\mathrm{ChO5}^{\top}$ $\left(=\right.$ KCTC $12238^{\top}=$ IAM $\left.15216^{\top}\right)$.
\end{abstract}

During the course of studies on the culturable aerobic bacterial community in granules that were used to treat wastewaters of brewing factories in Korea, a large number of novel bacterial strains were isolated (Im et al., 2003). One of these isolates (strain $\mathrm{Ch} 05^{\mathrm{T}}$ ) was found to be a member of the genus Paracoccus in the $\alpha$-Proteobacteria lineage and was the subject of a taxonomic investigation.

The genus Paracoccus was first described by Davis et al. (1969); the genus currently comprises 17 species with validly published names. The members of the genus Paracoccus consist of Gram-negative cocci or short rods that show substantial metabolic versatility. Representatives are able to grow aerobically on a wide range of organic compounds. A number of species can also grow anaerobically, using nitrate as electron acceptor, and some representatives are able to use hydrogen as electron donor for chemoautotrophic growth. Phylogenetically, the genus belongs to the $\alpha-3$ subgroup of the

Published online ahead of print on 27 May 2005 as DOI 10.1099/ ijs.0.63494-0.

tPresent address: School of Civil, Urban and Geosystem Engineering, Seoul National University, Shillim-dong, Gwanak-gu, Seoul, Republic of Korea.

Abbreviation: UASB, upflow anaerobic sludge blanket.

The GenBank/EMBL/DDBJ accession number for the 16S rRNA gene sequence of strain $\mathrm{ChO5}^{\top}$ is $\mathrm{AB} 187584$.
Proteobacteria. Recently, Paracoccus seriniphilus (Pukall et al., 2003), Paracoccus yeei (Daneshvar et al., 2003) and Paracoccus zeaxanthinifaciens (Berry et al., 2003) were introduced.

Strain $\mathrm{Ch} 5^{\mathrm{T}}$ was isolated from granules involved in the treatment of wastewater from a beer-brewing factory in Chung-Ju, Republic of Korea. Anaerobic granules are bacterial aggregates that result from the flocculation of sludge in an upflow anaerobic sludge blanket (UASB) reactor (de Zeeuw \& Lettinga, 1980; Lettinga, 1995). They are composed of micro-organisms, inorganic nuclei and extracellular polymers (Fukuzaki et al., 1991; Shen et al., 1993). Great attention has been paid to the internal structure and catalytic activities of such granules (MacLeod et al., 1990; Schmidt \& Ahring, 1996). In our laboratory, the relationship between the structure and the resistance to toxic chemicals in anaerobic granules from a brewerywastewater-treatment UASB reactor was studied (Bae \& Lee, 1999; Bae et al., 2000). In a series of studies, we attempted to isolate micro-organisms from the anaerobic granules in order to investigate the community structure by using a culture system. Interestingly, the granules contained aerobic bacteria even though they had been kept under anaerobic conditions for 2 years. Strain $\mathrm{Ch} 05^{\mathrm{T}}$ is one of the dominant bacterial isolates grown under aerobic conditions.

In the present study, we conducted a phylogenetic analysis on the basis of 16S rRNA gene sequences, DNA-DNA 
relatedness and some important phenotypic characteristics to determine the precise taxonomic position of this strain. On the basis of the results obtained in this study, we propose that strain $\mathrm{Ch} 5^{\mathrm{T}}$ should be placed in the genus Paracoccus as the type strain of a novel species.

For the isolation of aerobic bacteria, brownish black granules (around $2 \mathrm{~mm}$ in diameter) from a brewerywastewater-treating UASB reactor, which had been operated anaerobically for 2 years, were homogenized by using an Ace homogenizer (Nihonseiki). The suspension was spread on R2A agar plates (Scharlau) after being serially diluted with $50 \mathrm{mM}$ phosphate buffer $(\mathrm{pH} \mathrm{7 \cdot 0)}$. The plates were incubated at $30^{\circ} \mathrm{C}$ for 2 weeks. Single colonies on the plates were purified by transferring them onto new plates and incubating them once again under the same conditions. The purified colonies were tentatively identified by means of partial sequences of $16 \mathrm{~S}$ rRNA. Ch0 $05^{\mathrm{T}}$ was one of the dominant isolates appearing on the plates under aerobic conditions.

A Gram-reaction was performed by using the non-staining method as described by Buck (1982). Cell morphology was observed under a Nikon E600 light microscope at $\times 1000$, using cells grown for 2 days at $30^{\circ} \mathrm{C}$ on R2A agar. Catalase and oxidase tests were performed by using the procedures outlined by Cappuccino \& Sherman (2002). The utilization of various substrates as sole carbon sources, and some physiological characteristics, were determined with API $32 \mathrm{GN}$ and API 20NE galleries according to the instructions of the manufacturer (bioMérieux). Nitrate and nitrite reduction were later confirmed by inoculating cells, in each case, into three serum bottles $(25 \mathrm{ml})$ containing $13 \mathrm{ml} \mathrm{R} 2 \mathrm{~A}$ medium, while nitrate and nitrite were added as $\mathrm{KNO}_{3}$ and $\mathrm{NaNO}_{2}$ at concentrations of $10 \mathrm{mM}$. The reduction of nitrate and nitrite was monitored by ion chromatograph (model 790 personal IC; Metrohm) equipped with a conductivity detector and anion exchange column (Metrosep Anion Supp 4; Metrohm). The physiological characteristics of strain $\mathrm{Ch} 05^{\mathrm{T}}$ and related type strains are summarized in Table 1.

Extraction of genomic DNA, PCR-mediated amplification of the 16S rRNA gene sequences and sequencing of purified PCR products were carried out according to Im et al. (2004). The 16S rRNA gene sequences of related taxa were obtained from GenBank. The multiple alignments were performed using the CLUSTAL X program (Thompson et al., 1997). Gaps were edited in the BioEdit program (Hall, 1999). Evolutionary distances were calculated using Kimura's twoparameter model (Kimura, 1983). A phylogenetic tree was constructed by using the neighbour-joining methods (Saitou \& Nei, 1987) in the MEGA2 program (Kumar et al., 2001), with bootstrap values based on 1000 replications (Felsenstein, 1985) (Fig. 1). The 16S rRNA gene sequence of strain $\mathrm{Ch}^{\mathrm{T}} 5^{\mathrm{T}}$ was a continuous stretch of $1386 \mathrm{bp}$. Sequence-similarity calculations after neighbour-joining analysis indicated that the closest relatives of strain
Table 1. Comparison of selected characteristics of $P$. koreensis sp. nov. $\mathrm{ChO5}^{\top}$ with those of its nearest phylogenetic neighbours within the genus Paracoccus

Strains: 1, P. koreensis $\mathrm{Ch}^{2} 5^{\mathrm{T}}$; 2, P. kocurii KCTC $12189^{\mathrm{T}}$; 3, P. alkenifer KCTC $12188^{\mathrm{T}}$; 4, P. solventivorans KCTC $12190^{\mathrm{T}}$. All strains are Gram-negative and short rod- to coccus-shaped and are positive for oxidase and catalase activities and assimilation of acetate, 3-hydroxybutyrate, DL-lactate and propionate. All strains are negative for assimilation of adipate, L-arabinose, caprate, citrate, L-fucose, D-glucose, 3-hydroxybenzoate, inositol, itaconate, 2-ketogluconate, malate, maltose, mannitol, mannose, D-melibiose, $\mathrm{N}$-acetylglucosamine, rhamnose, salicin, suberate and D-sucrose, indole production, acid production from glucose and for the production of arginine dihydrolase, urease, $\beta$-glucosidase, $\beta$ galactosidase and protease (casein hydrolysis).

\begin{tabular}{|lcccc|}
\hline Characteristic & $\mathbf{1}$ & $\mathbf{2}$ & $\mathbf{3}$ & $\mathbf{4}$ \\
\hline Denitrification & - & + & + & + \\
Carbon utilization & & & & \\
$\quad$ L-Alanine & + & - & - & - \\
Gluconate & - & - & - & + \\
Glycogen & + & - & - & - \\
Histidine & + & - & + & + \\
4-Hydroxybenzoate & - & - & - & + \\
5-Ketogluconate & - & - & + & - \\
Malonate & - & - & + & + \\
Phenylacetate & - & - & + & - \\
L-Proline & + & - & + & + \\
D-Ribose & + & - & - & - \\
L-Serine & - & - & + & + \\
D-Sorbitol & + & - & - & - \\
Valerate & + & - & + & + \\
\hline
\end{tabular}

Ch05 ${ }^{\mathrm{T}}$ were Paracoccus solventivorans $(97 \cdot 5 \%)$, Paracoccus alkenifer (96.9\%) and Paracoccus kocurii (96.4\%), and the phylogenetic distance from other Paracoccus species with validly published names was more than $4 \%$.

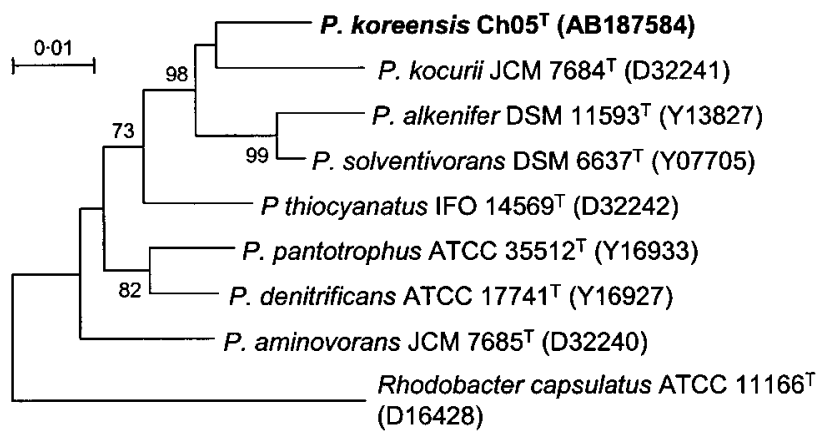

Fig. 1. Phylogenetic tree, constructed from a comparative neighbour-joining analysis of $16 \mathrm{~S}$ rRNA gene sequences, showing the relationships between $P$. koreensis $\mathrm{Ch05}^{\top}$ and other related species. Bootstrap values (expressed as percentages of 1000 replications) greater than $70 \%$ are shown at branch points. Bar, 1 substitution per 100 nt positions. 
The $\mathrm{G}+\mathrm{C}$ content of the chromosomal DNA was determined as described by Mesbah et al. (1989), using reversephase HPLC. Quinones were extracted from cells grown on a nutrient broth (Scharlau) and then analysed as described by Komagata \& Suzuki (1987), using reverse-phase HPLC. Cellular fatty acids were analysed in micro-organisms grown on trypticase soy agar (Scharlau) for 2 days. The cellular fatty acids were saponified, methylated and extracted according to the protocol of the Sherlock Microbial Identification System (MIDI). The fatty acids were analysed using gas chromatography (6890; Hewlett Packard) and identified by using the Microbial Identification software package (Sasser, 1990).

The $\mathrm{G}+\mathrm{C}$ content of genomic DNA of strain $\mathrm{Ch} 05^{\mathrm{T}}$ was $69 \mathrm{~mol} \%$, while those of Paracoccus species were in the range 63-71 mol\% (Harker et al., 1998). The respiratory quinone system of $\mathrm{Ch} 5^{\mathrm{T}}$ supports the affiliation of this strain to the $\alpha$-Proteobacteria, as the majority of Paracoccus species contain Q-10 as the major quinone. The fatty acid profile of strain $\mathrm{Ch} 5^{\mathrm{T}}$ was composed mainly of $\mathrm{C}_{18: 1}(79 \cdot 6 \%)$, $\mathrm{C}_{18: 0}(13 \cdot 4 \%), \mathrm{C}_{10: 0} 3-\mathrm{OH}(2 \cdot 4 \%)$ and $\mathrm{C}_{16: 0}(2 \cdot 3 \%)$. A comparison of the fatty acid profile of $\mathrm{Ch} 05^{\mathrm{T}}$ with those of phylogenetically related strains is presented in Table 2 . The fatty acid profile of strain $\mathrm{Ch} 05^{\mathrm{T}}$ is relatively simple compared with the others.

DNA-DNA hybridization experiments were performed between $\mathrm{Ch} 5^{\mathrm{T}}$ and type strains of the phylogenetically closest Paracoccus species, using the method described by Ezaki et al. (1989) with photobiotin-labelled DNA probes and microdilution wells. The DNA-DNA relatedness values for strain $\mathrm{Ch} 5^{\mathrm{T}}$ with respect to the type strains of the phylogenetically closest Paracoccus species were in the range $14-36 \%$, which is sufficiently low to allow the assignment of strain $\mathrm{Ch}_{05}{ }^{\mathrm{T}}$ to the genus Paracoccus as a novel species. On the basis of the data and observations described above, strain $\mathrm{Ch} 05^{\mathrm{T}}$ should be assigned to the genus Paracoccus as the type strain of a novel species, for which the name Paracoccus koreensis sp. nov. is proposed.

\section{Description of Paracoccus koreensis sp. nov.}

Paracoccus koreensis (ko.re.en'sis. N.L. masc. adj. koreensis pertaining to Korea, the location of the granule samples from which the type strain was isolated).

Cells are Gram-negative, aerobic, non-motile, short rod- to coccus-shaped and $0 \cdot 5-1 \cdot 0 \mu \mathrm{m}$ by $1 \cdot 0-1 \cdot 5 \mu \mathrm{m}$ in size after 2 days culture on R2A agar. Colonies grown on R2A agar for 1-2 days are smooth, circular, non-glossy, creamy white and convex. Grows well at $15-37^{\circ} \mathrm{C}$ and at $\mathrm{pH}$ 6-8, but does not grow at 4 or $45^{\circ} \mathrm{C}$. Catalase- and oxidase-positive; shows oxidative metabolism. Unable to grow anaerobically using nitrate as electron acceptor. Unable to reduce nitrate but able to reduce nitrite. Substrate utilization, enzyme production, acid production and other physiological characteristics are indicated in Table 1. Q-10 is the predominant ubiquinone. $\mathrm{C}_{18: 1}(79 \cdot 6 \%)$ and $\mathrm{C}_{18: 0}(13 \cdot 4 \%)$ are the major
Table 2. Cellular fatty acid profile of $P$. koreensis sp. nov. $\mathrm{ChO5}^{\top}$ and related type strains of Paracoccus species

Strains: 1, P. koreensis $\mathrm{Ch}^{\mathrm{T}} 5^{\mathrm{T}}$; 2, P. kocurii KCTC $12189^{\mathrm{T}}$; 3, P. alkenifer KCTC $12188^{\mathrm{T}}$; 4, P. solventivorans KCTC $12190^{\mathrm{T}}$. tr, Trace amounts $(<1 \%)$.

\begin{tabular}{|c|c|c|c|c|}
\hline Fatty acid & 1 & 2 & 3 & 4 \\
\hline \multicolumn{5}{|l|}{ Saturated } \\
\hline $\mathrm{C}_{12: 0}$ & - & $1 \cdot 1$ & - & - \\
\hline $\mathrm{C}_{14: 0}$ & - & $\operatorname{tr}$ & - & - \\
\hline$C_{16: 0}$ & $2 \cdot 3$ & $4 \cdot 0$ & $1 \cdot 6$ & - \\
\hline$C_{17: 0}$ & - & $3 \cdot 2$ & $2 \cdot 3$ & $2 \cdot 2$ \\
\hline $\mathrm{C}_{18: 0}$ & $13 \cdot 4$ & $14 \cdot 8$ & $4 \cdot 5$ & $7 \cdot 1$ \\
\hline $\mathrm{C}_{19: 0}$ & - & $1 \cdot 0$ & $0 \cdot 9$ & - \\
\hline \multicolumn{5}{|l|}{ Unsaturated } \\
\hline $\mathrm{C}_{20: 1} \omega 9 t$ & - & $2 \cdot 6$ & $1 \cdot 7$ & $1 \cdot 4$ \\
\hline \multicolumn{5}{|c|}{ Hydroxy fatty acids } \\
\hline $\mathrm{C}_{16: 0} 2-\mathrm{OH}$ & - & $1 \cdot 1$ & - & - \\
\hline $\mathrm{C}_{10: 0} 3-\mathrm{OH}$ & $2 \cdot 4$ & - & - & - \\
\hline $\mathrm{C}_{19: 0}$ cyclo $\omega 8 c$ & - & $34 \cdot 5$ & - & - \\
\hline \multicolumn{5}{|c|}{ Summed features ${ }^{\star}$} \\
\hline 3 & - & $\operatorname{tr}$ & $2 \cdot 3$ & $3 \cdot 2$ \\
\hline 7 & $79 \cdot 6$ & $36 \cdot 5$ & $86 \cdot 7$ & $86 \cdot 1$ \\
\hline \multicolumn{5}{|l|}{ Unknown $\dagger$} \\
\hline ECL $11 \cdot 798$ & $2 \cdot 3$ & - & - & - \\
\hline
\end{tabular}

* Summed features are groups of two or three fatty acids that cannot be separated by GLC with the MIDI system. Summed feature 3 contains $\mathrm{C}_{14: 0} 3-\mathrm{OH}$ and/or $\mathrm{C}_{16: 1}$ iso I; summed feature 7 contains $\mathrm{C}_{18: 1} \omega 7 c / \omega 9 t / \omega 12 t$.

$\dagger$ Unknown fatty acids have no name listed in the peak library file of the MIDI system and therefore cannot be identified. Equivalent chain lengths (ECL) are given.

cellular fatty acids. The $\mathrm{G}+\mathrm{C}$ content of the genomic DNA is $69 \mathrm{~mol} \%$ (as determined by HPLC).

The type strain, $\mathrm{Ch}_{0} 5^{\mathrm{T}}\left(=\right.$ KCTC $\left.12238^{\mathrm{T}}=\mathrm{IAM} 15216^{\mathrm{T}}\right)$, was isolated from granules used in the wastewater-treatment plant of a beer-brewing factory in Chung-Won, Republic of Korea.

\section{Acknowledgements}

This work was supported by Eco-Tecnopia-21, Ministry of Environment (grant 121-041-028), Gwacheon, Korea, and the Ministry of Science and Technology (Korea Science and Engineering Foundation).

\section{References}

Bae, J.-W. \& Lee, S.-T. (1999). Layered structure of UASB granules gives microbial population resistance to toxic chemicals. Biotechnol Lett 21, 159-162.

Bae, J.-W., Rhee, S.-K., Hyun, S.-H., Kim, I. S. \& Lee, S.-T. (2000). Layered structure of granules in upflow anaerobic sludge blanket 
reactor gives microbial populations resistance to metal ions. Biotechnol Lett 22, 1935-1940.

Berry, A., Janssens, D., Hümbelin, M. \& 10 other authors (2003). Paracoccus zeaxanthinifaciens sp. nov., a zeaxanthin-producing bacterium. Int J Syst Evol Microbiol 53, 231-238.

Buck, J. D. (1982). Nonstaining (KOH) method for determination of Gram reactions of marine bacteria. Appl Environ Microbiol 44, 992-993.

Cappuccino, J. G. \& Sherman, N. (2002). Microbiology: a Laboratory Manual, 6th edn. San Francisco: Pearson Education.

Daneshvar, M. I., Hollis, D. G., Weyant, R. S. \& 11 other authors (2003). Paracoccus yeeii sp. nov. (formerly CDC group EO-2), a novel bacterial species associated with human infection. J Clin Microbiol 41, 1289-1294.

Davis, D. H., Doudoroff, M., Stanier, R. Y. \& Mandel, M. (1969). Proposal to reject the genus Hydrogenomonas: taxonomic implications. Int J Syst Bacteriol 19, 375-390.

de Zeeuw, W. J. \& Lettinga, G. (1980). Use of anaerobic digestion for wastewater treatment. Antonie van Leeuwenhoek 46, 110-112.

Ezaki, T., Hashimoto, Y. \& Yabuuchi, E. (1989). Fluorometric deoxyribonucleic acid-deoxyribonucleic acid hybridization in microdilution wells as an alternative to membrane filter hybridization in which radioisotopes are used to determine genetic relatedness among bacterial strains. Int J Syst Bacteriol 39, 224-229.

Felsenstein, J. (1985). Confidence limit on phylogenies: an approach using the bootstrap. Evolution 39, 783-791.

Fukuzaki, S., Chang, Y. J., Nishio, N. \& Nagai, S. (1991). Characteristics of granular methanogenic sludges grown on lactate in a UASB reactor. J Ferment Bioeng 72, 465-472.

Hall, T. A. (1999). BioEdit: a user-friendly biological sequence alignment editor and analysis program for Windows 95/98/NT. Nucleic Acids Symp Ser 41, 95-98.

Harker, M., Hirschberg, J. \& Oren, A. (1998). Paracoccus marcusii sp. nov., an orange Gram-negative coccus. Int J Syst Bacteriol 48, 543-548.

Im, W.-T., Kang, M.-S., Park, H.-Y., Kim, M.-K. \& Lee, S.-T. (2003). Culturable bacterial strain's diversity of environmental samples. In Proceedings of the International Meeting of the Federation of Korean Microbiological Societies, abstract B4023, p. 165. Seoul: Federation of Korean Microbiological Societies.
Im, W.-T., Bae, H.-S., Yokota, A. \& Lee, S. T. (2004). Herbaspirillum chlorophenolicum sp. nov., a 4-chlorophenol-degrading bacterium. Int J Syst Evol Microbiol 54, 851-855.

Kimura, M. (1983). The Neutral Theory of Molecular Evolution. Cambridge: Cambridge University Press.

Komagata, K. \& Suzuki, K. (1987). Lipids and cell-wall analysis in bacterial systematics. Methods Microbiol 19, 161-203.

Kumar, S., Tamura, K., Jacobsen, I.-B. \& Nei, M. (2001). MEGA2: molecular evolutionary genetics analysis software. Bioinformatics 17, 1244-1245.

Lettinga, G. (1995). Anaerobic digestion and wastewater treatment systems. Antonie van Leeuwenhoek 67, 3-28.

MacLeod, F. A., Guiot, S. R. \& Costerton, J. W. (1990). Layered structure of biological aggregates produced in an upflow anaerobic sludge bed and filter reactor. Appl Environ Microbiol 56, 1598-1607.

Mesbah, M., Premachandran, U. \& Whitman, W. B. (1989). Precise measurement of the $\mathrm{G}+\mathrm{C}$ content of deoxyribonucleic acid by highperformance liquid chromatography. Int J Syst Bacteriol 39, 159-167.

Pukall, R., Laroche, M., Kroppenstedt, R. M., Schumann, P., Stackebrandt, E. \& Ulber, R. (2003). Paracoccus seriniphilus sp. nov., an L-serine-dehydratase-producing coccus isolated from the marine bryozoan Bugula plumosa. Int J Syst Evol Microbiol 53, 443-447.

Saitou, N. \& Nei, M. (1987). The neighbor-joining method: a new method for reconstructing phylogenetic trees. Mol Biol Evol 4, 406-425.

Sasser, M. (1990). Identification of bacteria by gas chromatography of cellular fatty acids. MIDI Technical Note 101. Newark, DE: MIDI.

Schmidt, J. E. \& Ahring, B. K. (1996). Acetate and hydrogen metabolism in intact and disintegrated granules from an acetate-fed, $55^{\circ} \mathrm{C}$, UASC reactor. Biotechnol Bioeng 49, 229-246.

Shen, C. F., Kosaric, N. \& Blaszczyk, R. (1993). The effect of selected heavy metals ( $\mathrm{Ni}, \mathrm{Co}$ and $\mathrm{Fe}$ ) on anaerobic granules and their extracellular polymeric substance (EPS). Water Res 27, 25-33.

Thompson, J. D., Gibson, T. J., Plewniak, F., Jeanmougin, F. \& Higgins, D. G. (1997). The CLUSTAL_X Windows interface: flexible strategies for multiple sequence alignment aided by quality analysis tools. Nucleic Acids Res 25, 4876-4882. 